\title{
The Potential for Horses to Disperse Alien Plants Along Recreational Trails
}

\author{
Floye H. Wells ${ }^{1}$ and William K. Lauenroth ${ }^{2}$ \\ Authors are ${ }^{1}$ Graduate Student and ${ }^{2}$ Professor, Graduate Degree Program in Ecology, Colorado State University, Fort Collins, CO 80523.
}

\begin{abstract}
Plant invasions are rapidly becoming an important threat to the conservation of wildlands. Understanding how potentially invasive plants are dispersed to new habitats is a critical step in the process of understanding such invasions. Our objective was to characterize the potential for long-distance transport of plant species in the digestive tract of horses along recreational trails. We sampled horse dung along the first $4000 \mathrm{~m}$ of the Lower Piney River trail in the White River Forest of western Colorado. We evaluated the seed content of each sample by applying standard methods for soil seed bank analysis. We found 20 species and 564 seedlings. Twelve of the species were graminoids, 6 were forbs, 1 was a shrub, and 1 was a tree. The species were evenly divided between natives and aliens, but $85 \%$ of the seedlings were aliens. An average of 47 seedlings emerged per sample, but the range was from 4 to 192 . Our results make it clear that horses, and very likely all pack stock used on recreational trails, represent a potentially important dispersal vector for alien plants into western wildlands.
\end{abstract}

\section{RESUMEN}

Las invasiones de plantas se están convirtiendo rápidamente en una amenaza para la conservación de los terrenos silvestres. Entender como las plantas potencialmente invasoras son dispersadas hacia nuevos hábitats es un paso crítico en el proceso de comprender tales invasiones. Nuestro objetivo fue caracterizar el potencial de los caballos para transportar especies vegetales en su tacto digestivo por largas distancias a través de caminos recreativos. Muestreamos excretas de caballo a través de los primeros 4000 m del camino "Lower Piney River" en el bosque White River del oeste de Colorado. Evaluamos el contenido de semilla de cada muestra aplicando los métodos estándar para análisis del banco de semillas del suelo. Encontramos 20 especies y 564 plántulas, 12 de las especies fueron gramíneas, seis hierbas, una arbustiva, y un árbol. Las especies estuvieron equitativamente repartidas entre nativas e introducidas, pero $85 \%$ de las plántulas fueron introducidas. En promedio 47 plántulas emergieron por muestra, pero el rango fue de 4 a 192. Nuestros resultados dejan claro que los caballos, y muy probablemente todos los implementos de acampar usados en los caminos recreativos representan un vector potencialmente importante de dispersión de semillas de especies introducidas a los tierras silvestres del oeste.

Key Words: invasive plants, Colorado, Rocky Mountains, endozoochory, wildlands, seedling dispersal, dung, seeds, seedlings

\section{INTRODUCTION}

Alien plant species are capable of altering native communities at the population, community, and ecosystem levels (Vitousek et al. 1997; Mack et al. 2000). The causes of invasions are variable but two things are necessary: a suitable environment and a seed source. In order to protect native communities from the alterations caused by aggressive alien plants, it is critical to know which aliens are capable of surviving in which environments and how their seeds are dispersed. For aliens that are already established, we generally know the types of locations favored by each species, but we usually do not know how the seeds reach new locations, especially when new populations occur far from existing ones. As a rule, long distance dispersal is rare and difficult to quantify (Cain et al. 2000), but if we want to protect native communities that we know are at risk from particular alien species, we must gain a clearer understanding of how those plants travel long distances.

This work was supported by the Colorado State University Experiment Station through grant 1-57661 and by the National Science Foundation through grant 0217631.

Correspondence: William K. Lauenroth, Graduate Degree Program in Ecology, Colorado State University, Fort Collins, CO 80523. Email: William.Lauenroth@ColoState.edu

Manuscript received 24 July 2006; manuscript accepted 5 August 2007
There is increasing evidence that large mammals can play a crucial role in dispersing seeds over long distances (Janzen 1984; Myers et al. 2004; Cosyns et al. 2005). Many seeds are able to survive the passage through cattle, sheep, rabbits, and deer (Gardner et al. 1993; Campbell and Gibson 2001; Pakeman et al. 2002; Myers et al. 2004). In a study in which horses were fed a mixture of weedy seeds, the authors found that many species were able to pass through horses with little or no loss in viability and that peak transmission occurred 3 to 4 days after consumption, with some species being transmitted up to 10 days later (St. John Sweeting and Morris 1990).

Recreational trails in western wild lands represent corridors that connect the front country and the backcountry, and many trails are used by people with horses and other pack stock. The Backcountry Horsemen of America claims more than 16000 members in 19 states (http://www.backcountryhorse.com), which is likely a fraction of the number of people who ride horses on recreational trails. The large number of horses on public lands and the potential for them to carry alien seeds could make horses an important vector for alien plant dispersal into remote wildlands. It is common for horses to graze in "weedy" pastures and for their feed to be contaminated with alien plants; therefore, one would expect that horses are capable of carrying in a wide variety of alien species and 
depositing them on the trail. Surprisingly, very little is known about the seeds dispersed in this manner along trails (but see Campbell and Gibson 2001).

The overall goal of our study was to characterize the potential for long-distance transport of plant species by horses along recreational trails. We collected horse manure along a trail and the associated trailhead in the Rocky Mountains of Colorado during peak hunting season when horse use is at its highest and evaluated the viable seed content by applying standard soil seed bank methods. Our specific objectives were 1) to identify the species present in horse manure, 2) to quantify the number of seedlings per species, and 3) to examine the proportion of species and seedlings that were aliens.

\section{SITE DESCRIPTION}

All samples were gathered in mid-October on the Lower Piney River trail and associated parking area $\left(39^{\circ} 42^{\prime} 30^{\prime \prime} \mathrm{N}\right.$, $\left.106^{\circ} 25^{\prime} 50^{\prime \prime} \mathrm{W}\right)$. The trailhead is 27.4 kilometers north of Vail, Colorado on a maintained dirt road, $2.5 \mathrm{~km}$ from a guest ranch that uses the trail for horseback rides. We collected samples during hunting season when many of the horses on the trail were brought in on trailers from other locations. The trail receives relatively low use, about 500 users per year according to trail register data, but has more horse travel than other trails in the Vail area (Beth Borton, personal communication, July 2004). The trail starts at an elevation of $2795 \mathrm{~m}$ and follows the Piney River. The trail passes through montane forests and meadows.

\section{METHODS}

We collected recent horse dung in the first $4000 \mathrm{~m}$ of the trail and at trailheads. We determined whether a sample was recent by whether or not it had hardened. We collected a total of 12 samples and assessed the seed content of each sample following standard methods for soil seed bank studies (Thompson and Grime 1976; Coffin and Lauenroth 1989). Samples were dried and stored in an unheated location from October 2003 until February 2004 and then thoroughly mixed and split into quarters to reduce the volume of material. We spread one quarter of each sample over a layer of sterile potting soil in the greenhouse. Trays were watered daily and fertilized with Miracle Gro every 2 to 3 weeks. We did not apply any special germination techniques under the assumption that the seeds of interest are those that germinate easily given adequate water, nutrients, and light. We converted seedling number per tray to number per sample by multiplying by four.

Seedlings were removed and placed in larger pots as they emerged to ensure space and nutrients for new seedlings. After 4 months and a 3 -week period in which no new seedlings emerged, the experiment was terminated and the trays were discarded. We identified plants using Weber and Wittmann (2001), but gave preference to the USDA PLANTS Database (USDA, NRCS 2004) when assigning nomenclature and origin. We included Poa pratensis L. as an alien species because we determined that this was the most likely form in our samples.
We listed plants that we could identify to the genus but not the species level as natives to avoid overreporting the number of alien species.

\section{RESULTS}

Twenty species emerged from our 12 samples: 10 natives and 10 aliens (Table 1). Although there were equal numbers of native and alien species, the distribution of seedlings was heavily weighted towards aliens. Aliens accounted for $85 \%$ of all the seedlings that emerged from the samples. Twelve of the species were grasses, sedges, and rushes (graminoids), 6 were forbs contributing 128 seedlings, 1 was a tree with 8 seedlings, and 1 was a shrub with 4 seedlings. The average number of seedlings per species was 28 . This average is misleading because 2 species, both of which were aliens, accounted for 432 of the total of 564 seedlings.

Poa pratensis was present in 9 of the 12 samples and contributed 332 or $59 \%$ of the seedlings. More than half of the Poa pratensis seedlings (172) were found in a single sample (Table 1). Amaranthus retroflexus accounted for $18 \%$ of the seedlings and all of its seedlings (100) were found in a single sample collected 50 meters from the trailhead.

An average of 47 seedlings emerged per sample, but the range was from 4 to 192 (Fig. 1a). Three samples contained more than 100 seedlings and 3 had fewer than 10 . The samples with the largest number of seedlings had a single species that accounted for most of the seedlings. For instance, the sample with the largest number of seedlings, which was collected 877 meters from the trailhead, contained 192 seedlings, and 172 of them were Poa pratensis.

The distribution of species per sample was more even than the distribution of seedlings, but the range was again quite large, from 1 to 7 (Fig. 1b). The average number of species per sample was 3. All but one of the samples contained at least one alien species and 4 samples contained no native species. The sample collected at $1 \mathrm{~km}$ from the trailhead contained a single native species, Pascopyrum smithii.

\section{DISCUSSION}

We found viable seeds from graminoids, forbs, a shrub, and a tree in samples of horse dung. The number of seedlings per species ranged from fewer than 5 to more than 300. Most of the samples had fewer than 50 seedlings and 3 had 100 or more seedlings. We found an equal number of native and alien species, but aliens accounted for over $80 \%$ of the seedlings. This suggests that either aliens had more seeds per species, or greater viability, or both. Eleven of our 12 samples contained alien species and the 3 samples with over 100 seedlings contained either Poa pratensis (2 samples) or Amaranthus retroflexus (1 sample), both alien species.

Even though the alien species in our samples are common species that are not a priority for management, our most important result is that horses have the potential to disperse a large number of seeds from a wide variety of plant types. Because horses take an average of 3 to 4 days, and up to 10 days, to eliminate the seeds they ingest, they represent an 
Table 1. Plant species found in samples along with information about the life form, origin, the location of the samples in which each species occurred, and the total number of seedlings for each species. TH1, TH2, and TH3 refer to samples collected at the trailhead. An asterisk following a plant name indicates that that species was found established in the first $2000 \mathrm{~m}$ of the trail on or within $4 \mathrm{~m}$ of the trail (Wells 2005 ).

\begin{tabular}{|c|c|c|c|c|}
\hline Name & Life form & Origin & Locations (m from trailhead) & Total no. of seedlings \\
\hline Amaranthus retroflexus $\mathrm{L}$. & Forb & Alien & 50 & 100 \\
\hline Avena sativa $\mathrm{L}$. & Grass & Alien & 50 & 4 \\
\hline Betula fontinalis Sargent & Tree & Native & 174,3051 & 8 \\
\hline Bromus inermis Leysser* & Grass & Alien & 500 & 8 \\
\hline Bromus tectorum $\mathrm{L}$. & Grass & Alien & 1846 & 4 \\
\hline Capsella bursa-pastoris (L.) Medicus* & Forb & Alien & 174 & 8 \\
\hline Carex spp. & Grass & Native & 877,3051 & 20 \\
\hline Chrysothamnus nauseosus (Pallas) Britton & Shrub & Native & 877 & 4 \\
\hline Dactylis glomerata $\mathrm{L} .{ }^{*}$ & Grass & Alien & 174 & 4 \\
\hline Frageria vesca $\mathrm{L}$. & Forb & Native & 174 & 4 \\
\hline Juncus balticus Willd. ${ }^{*}$ & Grass & Native & TH1 & 8 \\
\hline Juncus confuses Coville & Grass & Native & TH3 & 4 \\
\hline Juncus spp. & Grass & Native & 3051 & 4 \\
\hline Pascopyrum smithii (Rydberg) Löve* & Grass & Native & 1000,2616 & 12 \\
\hline Pentaphylloides floribunda (Pursh) Löve* & Forb & Native & 30 & 4 \\
\hline Poa spp. & Grass & Native & TH1, 174 & 16 \\
\hline Poa pratensis $\mathrm{L} .{ }^{*}$ & Grass & Alien & $\begin{array}{l}\text { TH1, TH2, TH3, 50, 174, 877, } \\
1846,2616,3051\end{array}$ & 332 \\
\hline Polygonum arenastrum Boreau* & Forb & Alien & TH2 & 4 \\
\hline Setaria viridis (L.) P. Beauvois & Grass & Alien & TH1, TH3 & 8 \\
\hline Spergularia rubra Presl and Presl* & Forb & Alien & 174,281 & 8 \\
\hline
\end{tabular}

important vector for long distance seed dispersal from where the horses are kept to wildlands. Many horses are grazed in pastures that contain "weedy species" and, in some cases, in pastures that contain aggressive alien species. Many horses are transported to backcountry trails where they can then introduce new species. The potential for horses to introduce new species increases with the time they spend in the backcountry. In 3 days, a pack string can cover $80 \mathrm{~km}$ of trail, and in 10 days a pack string can cover over $240 \mathrm{~km}$ of trail.

A similar study conducted in mostly oak-hickory forests in southern Illinois found that $44 \%$ of the species in horse manure were aliens, but that only one of those species was present in the resident vegetation (Campbell and Gibson 2001). In contrast, they found that many of the species in horse manure were present in the soil seed bank. This demonstrates either 1) that horses are contributing directly to the seed bank, or 2) that the types of seeds that are able to survive digestion by horses are the same seeds that form persistent seed banks. The idea that the adaptations needed to survive digestion are the same as those necessary for long-term survival in the seed bank has been suggested by Janzen (1984) and Pakeman et al. (2002). Nine of the species we found in our dung samples were also found in the vegetation along the trail (Table 1).

If it is true that the seeds horses deposit are contributed to the soil seed bank, it could be years before an introduction is detected. Establishment in a new location is difficult for any species (Cavers and Harper 1967; Burke and Grime 1996), but a species certainly has an advantage if it can remain dormant in seed form until environmental conditions for survival to adulthood can be met.

There could also be a feedback between seeds deposited by horses and the disturbance created by horses on the trail.
Previous research has shown that disturbance often aids invasion by alien plant species (Hobbs and Huenneke 1992; Burke and Grime 1996) and that horses create a greater disturbance than hikers alone. Horses turn up the soil more than hikers, which leads to increased sediment yield and, therefore, more erosion (Deluca et al. 1998), and horses are also more likely to expose mineral soil and have a greater impact on relative cover of the resident vegetation (Cole and Spildie 1998).

Campbell and Gibson (2001) distributed horse dung along a trail and found that very few species in the dung were able to establish in the resident vegetation. This finding highlights the difficulty inherent in establishment, but it does not rule out the possibility. Successful invasions are rare (Williamson and Fitter 1996), but they can occur if given the right environmental conditions and a sufficient seed supply.

The seed dispersal capabilities of large herbivores are well documented (Myers et al. 2004; Cosyns et al. 2005; Mouissie et al. 2005). Our results confirmed that horses used for recreational riding on the Lower Piney River trial transported large numbers of seeds in their digestive tract and deposited them either at the trailhead or along the trail. Because the transportation time for horses from their home pastures to the trail head is often short, any plant that is present in the home pasture has a greater than zero probability of being dispersed to the trailhead or the trail. Although many Western states and federal agencies have rules for the use of certified weed-free forage for horses and other pack stock on public wildlands, the potential for horses to transport noxious weeds in their digestive tracts seems to have received less notice.

Our work is clearly just an example of the possible role that pack stock could play in dispersal of alien plants into wildlands. Substantial new research will be needed to de- 

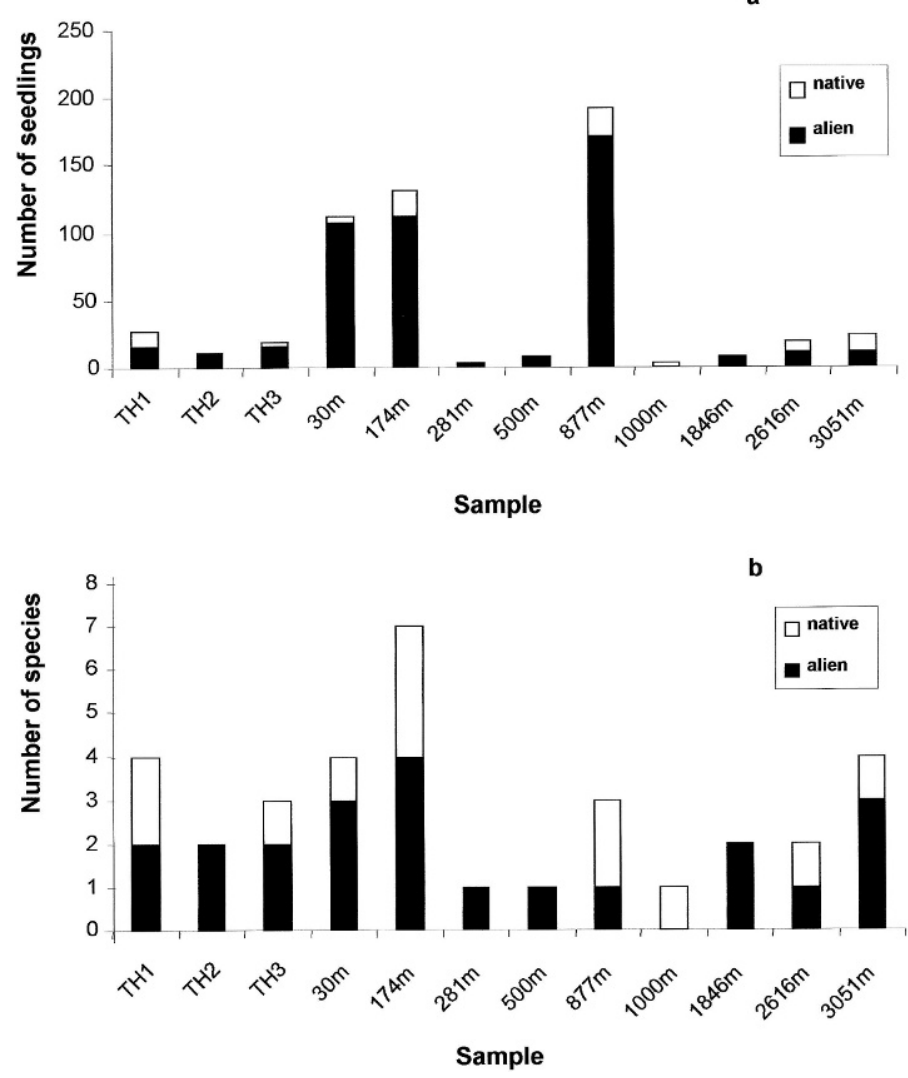

Figure 1. $\mathbf{a}$, The number of seedlings and $\mathbf{b}$, the number of species present in each sample, divided into native and alien categories, and the distance (in $\mathrm{m}$ ) at which that sample was collected from the trailhead. Three of the samples were collected from the trailhead: TH1, TH2, and $\mathrm{TH} 3$.

termine how important our results are for wildlands across the public lands in the West. Many western trails receive considerably more recreational stock use than the Lower Piney River Trail in the White River National Forest, and some of the most heavily used trails are in wilderness areas (e.g., Frank Church-River of No Return Wilderness).

\section{MANAGEMENT IMPLICATIONS}

Public land managers need to be very aware of the potential for riding and pack stock to transport alien plant seeds for long distances along recreational trails. In addition to feeding weedfree forage on public wildlands, suggestions for feeding weedfree forage for several days before transporting stock to trailheads and trails should result in an additional decrease in the likelihood of noxious weed dispersal. Posting such information on web sites used by backcountry riders and packers such as Back Country Horsemen of America (http://www. backcountryhorse.com/index.htm) and through outfitting associations (http://www.wyoga.org/) and dude ranch associations (http://www.coloradoranch.com/) would represent a first step in increasing awareness of the threat posed by recreational stock. With over 16000 backcountry riders in the United States, a small decrease in the probability that the average horse will introduce a noxious plant into a public wildland could have a large influence on the ongoing invasion of native communities and ecosystems.

\section{LITERATURE CITED}

Burke, M. J. W., And J. P. Grime. 1996. An experimental study of plant community invasibility. Ecology 77:776-790.

Cain, M. L., B. G. Milligan, and A. E. Strand. 2000. Long-distance seed dispersal in plant populations. American Journal of Botany 87:1217-1227.

Campbell, J. E., and D. J. Gibson. 2001. The effect of seeds of exotic species transported via horse dung on vegetation along trail corridors. Plant Ecology 157:23-25.

Cavers, P. B., and J. L. Harper. 1967. Studies in dynamics of plant populations. I. Fate of seed and transplants introduced into various habitats. Journal of Ecology 55:59-71.

Coffin, D. P., and W. K. Lauenroth. 1989. Spatial and temporal variation in the seed bank of a semiarid grassland. American Journal of Botany 76:5358.

Cole, D. N., ANd D. R. SpILDIE. 1998. Hiker, horse and llama trampling effects on native vegetation in Montana, USA. Journal of Environmental Management 53:61-71.

Cosyns, E., S. Claerbout, I. Lamoot, and M. Hoffmann. 2005. Endozoochorous seed dispersal by cattle and horse in a spatially heterogeneous landscape. Plant Ecology 178:149-162.

Deluca, T. H., W. A. Patterson, W. A. Freimund, and D. N. Cole. 1998. Influence of llamas, horses, and hikers on soil erosion from established recreation trails in western Montana, USA. Environmental Management 22:255-262.

Gardener, C. J., J. G. Mclvor, and A. Jansen. 1993. Passage of legume and grass seeds through the digestive-tract of cattle and their survival in feces. Journal of Applied Ecology 30:63-74.

HobBs, R. J., and L. F. Huenneke. 1992. Disturbance, diversity, and invasion: implications for conservation. Conservation Biology 6:324-337.

Janzen, D. H. 1984. Dispersal of small seeds by big herbivores-foliage is the fruit. American Naturalist 123:338-353.

Mack, R. N., D. Simberloff, W. M. Lonsdale, H. Evans, M. Clout, and F. Bazzaz. 2000. Biotic Invasions: Causes, epidemiology, global consequences, and control. Ecological Applications 10:689-710.

Mouissie, A. M., P. Vos, H. M. C. Verhagen, and J. P. Bakker. 2005. Endozoochory by free-ranging, large herbivores: ecological correlates and perspectives for restoration. Basic and Applied Ecology 6:547-558.

Myers, J. A., M. Vellend, S. Gardescu, and P. L. Marks. 2004. Seed dispersal by white-tailed deer: implications for long-distance dispersal, invasion, and migration of plants in Eastern North America. Oecologia 139:35-44.

Pakeman, R. J., G. Digneffe, and J. L. Small. 2002. Ecological correlates of endozoochory by herbivores. Functional Ecology 16:296-304.

St. John Sweeting, R. S., and K. A. Morris. 1990. Seed transmission through the digestive tract of the horse. Proceedings of the 9th Australian Weeds Conference; 6-10 August 1990. Adelaide, Australia: Weed Management Society of Australia, Inc. p. 137-139.

Thompson, K., and J. P. Grime. 1979. Seasonal-variation in the seed banks of herbaceous species in 10 contrasting habitats. Journal of Ecology 67:893921.

USDA, NRCS. 2004. The PLANTS Database, Version 3.5. National Plant Data Center, Baton Rouge, LA. Available at: http://plants.usda.gov. Accessed 15 Jaunary 2005.

Vitousek, P. M., C. M. Dantonio, L. L. Loope, M. Rejmanek, and R. Westbrooks. 1997. Introduced species: a significant component of human-caused global change. New Zealand Journal of Ecology 21:1-16.

Weber, W. A., and R. C. Whittmann. 2001. Colorado flora: Western slope. Boulder, CO: University Press of Colorado. 496 p.

WeLLs, F. H. 2005. Alien plants on recreational trails in the Colorado Rocky Mountains [thesis]. Fort Collins, C0: Colorado State University. 80 p.

Williamson, M., and A. FitTer. 1996. The varying success of invaders. Ecology 77:1661-1666. 